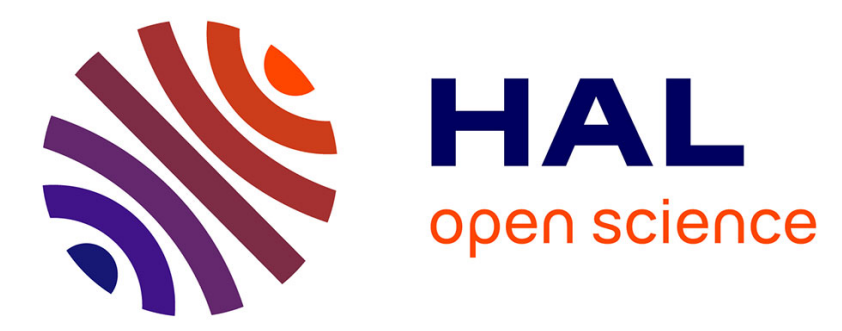

\title{
Design, Synthesis and Structural Analysis of New Macrocycles Containing Dispiro-1,3-dioxane Units
}

Ion Grosu, Maria Carmen Florian, Eric Condamine, Loïc Toupet, Yvan Ramondenc, Gérard Plé, Pascal Cardinaël

\section{- To cite this version:}

Ion Grosu, Maria Carmen Florian, Eric Condamine, Loïc Toupet, Yvan Ramondenc, et al.. Design, Synthesis and Structural Analysis of New Macrocycles Containing Dispiro-1,3-dioxane Units. Supramolecular Chemistry, 2007, 19 (6), pp.383-392. 10.1080/10610270600987903 . hal-00513493

\section{HAL Id: hal-00513493 \\ https://hal.science/hal-00513493}

Submitted on 1 Sep 2010

HAL is a multi-disciplinary open access archive for the deposit and dissemination of scientific research documents, whether they are published or not. The documents may come from teaching and research institutions in France or abroad, or from public or private research centers.
L'archive ouverte pluridisciplinaire HAL, est destinée au dépôt et à la diffusion de documents scientifiques de niveau recherche, publiés ou non, émanant des établissements d'enseignement et de recherche français ou étrangers, des laboratoires publics ou privés. 


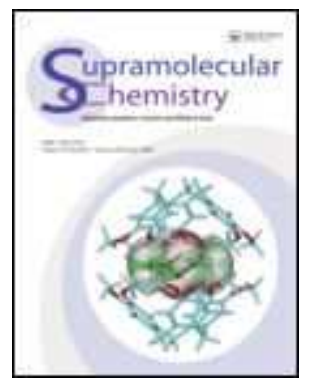

\section{Design, Synthesis and Structural Analysis of New Macrocycles Containing Dispiro-1,3-dioxane Units}

\begin{tabular}{|c|c|}
\hline Journal: & Supramolecular Chemistry \\
\hline Manuscript ID: & GSCH-2006-0061.R1 \\
\hline Manuscript Type: & Full Paper \\
\hline $\begin{array}{r}\text { Date Submitted by the } \\
\text { Author: }\end{array}$ & 19-Aug-2006 \\
\hline Complete List of Authors: & $\begin{array}{l}\text { Grosu, Ion; Babes-Bolyai University, Organic Chemistry } \\
\text { Florian, Maria; Babes-Bolyai University } \\
\text { Condamine, Eric; University of Rouen } \\
\text { Toupet, Loïc; University of Rennes } 1 \\
\text { Ramondenc, Yvan; University of Rouen } \\
\text { Plé, Gérard; University of Rouen } \\
\text { Cardinaël, Pascal; University of Rouen }\end{array}$ \\
\hline Keywords: & $\begin{array}{l}\text { macrocycles, crystal structure, dynamic NMR, dispiranes, 1,3- } \\
\text { dioxanes }\end{array}$ \\
\hline \multicolumn{2}{|c|}{$\begin{array}{l}\text { Note: The following files were submitted by the author for peer review, but cannot be converted } \\
\text { to PDF. You must view these files (e.g. movies) online. }\end{array}$} \\
\hline $\begin{array}{l}\text { Scheme1.cdx } \\
\text { Scheme2.cdx } \\
\text { Scheme3.cdx } \\
\text { Scheme4.cdx } \\
\text { Scheme5.cdx } \\
\text { Scheme6.cdx }\end{array}$ & \\
\hline
\end{tabular}

\section{今) ScholarONE" \\ Manuscript Central}




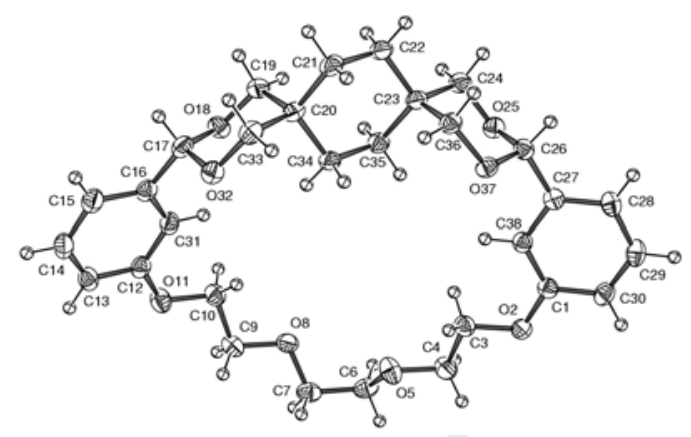




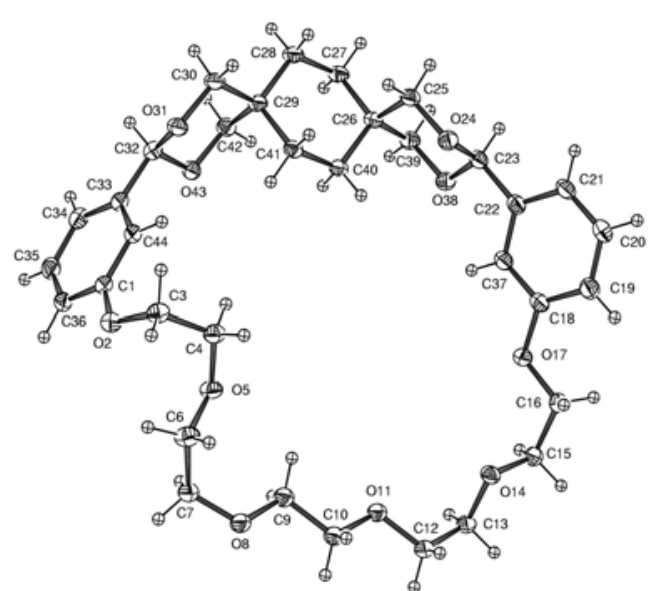

a

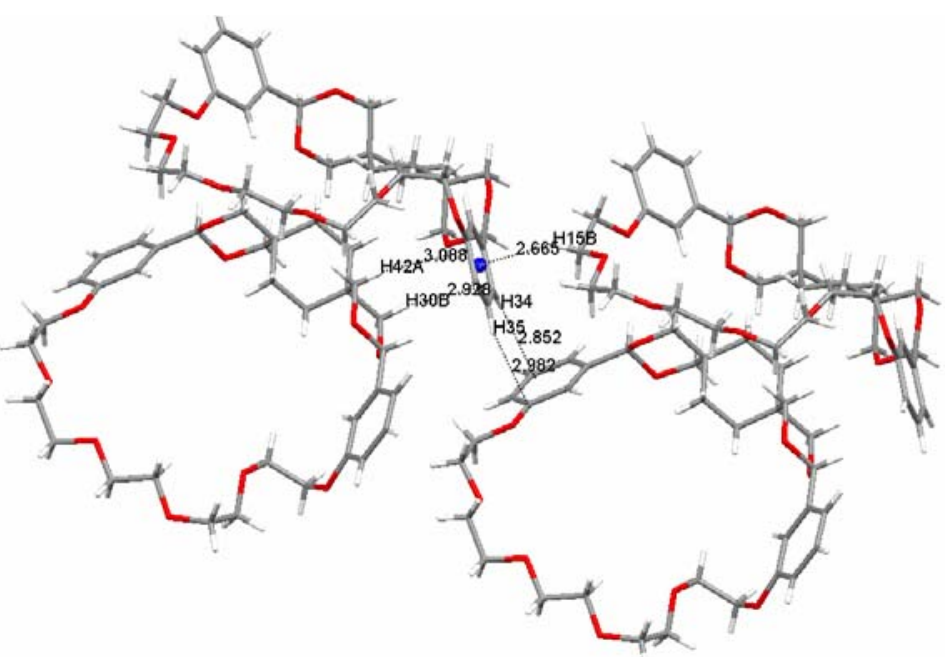

b 


\title{
Design, Synthesis and Structural Analysis of New Macrocycles Containing Dispiro-1,3-dioxane Units
}

\author{
MARIA CARMEN FLORIAN ${ }^{\mathrm{a}, \mathrm{b}}$, ION GROSU $^{* a}$, ERIC CONDAMINE ${ }^{\mathrm{b}}$, LOÏC TOUPET $^{\mathrm{c}}$, \\ YVAN RAMONDENC ${ }^{\mathrm{b}}$, GÉRARD PLÉ $^{\mathrm{b}}$ and PASCAL CARDINAËL ${ }^{\mathrm{b}}$ \\ a"Babes-Bolyai" University, Organic Chemistry Department and CCOCCAN, 11 Arany Janos str., 400028, \\ Cluj-Napoca, Romania \\ ${ }^{b}$ Université de Rouen, IRCOF, UMR 6014, Faculté des Sciences, 76821, Mont Saint-Aignan, France. \\ ${ }^{c}$ Université de Rennes 1, UMR C-6626, Campus de Beaulieu, Bat. 11A, 35042 Rennes, France
}

The synthesis and the structure of new macrocycles containing semiflexible dispiro-1,3dioxane units is reported. The structural analysis of the compounds is performed by high field NMR spectra, mass spectrometry investigations (MALDI, ESI-MS) and the solid state molecular structure obtained for two compounds by single crystal $\mathrm{X}$-ray diffractometry. The dynamics of the macrocycles promoted by the flipping of the middle cyclohexane ring of the dispirane units is investigated using low temperature NMR experiments

Keywords: Macrocycles, Crystal structure, Dynamic NMR, Dispiranes, 1,3-Dioxanes

\section{INTRODUCTION}

The synthesis and structural analysis of macrocyclic compounds as "hosts" for cations, anions and organic molecules is an important target in organic chemistry. ${ }^{1-22}$ Relevant features in high yield macrocyclisation reactions are the geometry of the substrate, which has to exhibit the preorganization ${ }^{23,24}$ required by the incorporation in the macrocycle, and the high number of heteroatoms of the reacting compounds, which can coordinate to cations and promote the macrocyclisation by template effect. ${ }^{25,26}$ Many papers ${ }^{27-37}$ deal with macrocycles that embed in their structure saturated oxygenated heterocycles pertaining to sugars, spiranes or bicycles. Recently, ${ }^{38,39}$ we reported the synthesis, structural analysis, and complexation ability of new macrocycles containing anancomeric spiro-1,3dioxane units (I, Scheme 1).

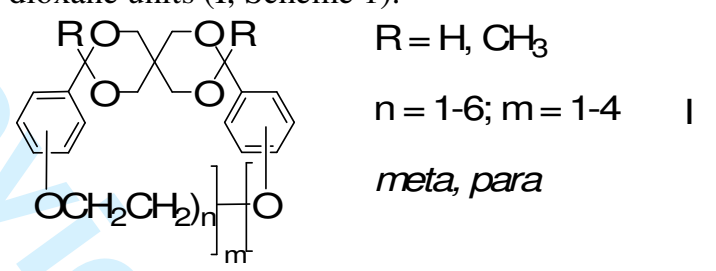

SCHEME 1. Macrocycles with monospirane units The synthesis of these derivatives was carried out in good yields, in high dilution or in template procedures and the reactions underwent with the obtaining of mixtures of monomers, dimers, trimers and tetramers. The NMR, X-ray diffractometry and mass spectrometry (MALDI, FAB and ESI-MS) supported structural analysis of the separated terms pointed out the "rigid" (anancomeric) conformational behavior of the spirane units, the intra and intermolecular $\pi$-stacking and the chemoselective ability of these macrocycles as hosts for cations and solvent molecules.

The investigations ${ }^{40,41}$ on the stereochemistry of substituted dispiranes with six-membered rings $\mathbf{1}$ showed separable syn and anti isomers (II-IV, Scheme 2). The syn structures (II and III) are chiral being built up by merging two monospirane units with similar configurations $(\mathrm{AB}$ and $\mathrm{BC}$ monospirane units are of $\mathrm{M}$ configuration for II and of $\mathrm{P}$ configuration for III). The anti structure is achiral and the merged monospirane units $(\mathrm{AB}$ and 
BC) display different configurations. Dispiranes 1 have semiflexible structure. The peripheral substituted 1,3-dioxane rings are "rigid", while the middle carbocycle is flipping. The conformational equilibrium is enantiomeric inversion for syn isomer and the conformational equilibrium of the centrosymmetric anti isomer occurs between two equivalent structures (homomeric equilibrium). The patterns of the ${ }^{1} \mathrm{H}$-NMR spectra ( $r t$ ) for the protons of ring B are very different for syn (two singlets) and anti structures (multiplets according to an $\mathrm{AA}^{\prime} \mathrm{BB}^{\prime}$ system) and the discrimination of these isomers and the determination of their ratio in mixtures of isomers are easily carried out by NMR.
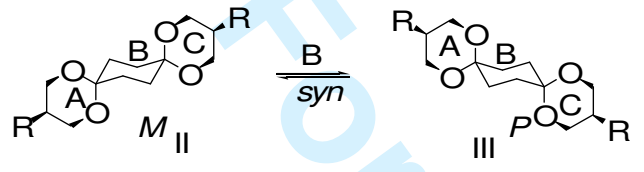

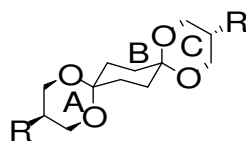
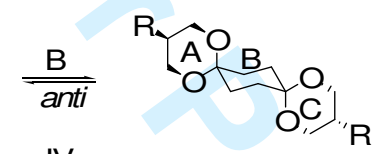

IV

A, $C=$ "rigid" ; $B=$ flipping

\section{1; $\mathrm{R}=\mathrm{CH}_{3}, \mathrm{C}_{6} \mathrm{H}_{5} ; \mathrm{COOCH}_{3} ; \mathrm{OCH}_{2} \mathrm{C}_{6} \mathrm{H}_{5}$}

SCHEME 2. Conformational equilibria for semiflexible dispiro-1,3-dioxanes

In order to develop the investigations of the host molecules with (poly)spirane units we designed new macrocycles which incorporate semiflexible dispirane units and we planed to study the reactivity of syn and anti isomers of dispiranes in the macrocyclisation reaction, and the influence of the semiflexible conformational behavior of the dispirane units on the structure and proprieties of the target macrocycles. The geometry of syn isomers is favorable to the macrocyclisation, while the reacting groups located at the extremities of the dispirane exhibit opposite orientations in the anti isomers and the macrocyclisation is expected to be difficult in this case.

\section{RESULTS AND DISCUSSIONS}

New macrocycles (3-7), containing dispiro-1,3dioxane units, were obtained by the template reaction of dispirane $\mathbf{2}$ with several ditosylated polyethyleneglycols. The reactions were performed starting from the 1/1 mixture of syn and anti isomers of dispirane 2 (obtained from 1,1,4,4tetrahydroxymethylcyclohexane $e^{42,43}$ and metahydroxybenzaldehyde), in acetonitril, and using $\mathrm{Cs}_{2} \mathrm{CO}_{3}$ as base and as template (Scheme 3; Table $1)$.

The mixture of isomers of $\mathbf{2}$ was used as substrate, on the one hand, because all the attempts to separate the syn and anti isomers by column chromatography or by crystallization failed (mainly because both isomers have a very low solubility in usual solvents) and on the other hand because we expected the high differences of reactivity between syn and anti isomers in the macrocyclisation reaction. The mass spectrometry investigations (MALDI, ESI-MS) of crude products showed the formation of monomers and oligomers (from dimers to tetramers) and the NMR spectra revealed important amounts of unreacted anti isomer of $\mathbf{2}$. The monomers are obtained only for 4-7 and only the syn isomer of $\mathbf{2}$ participates to their formation. The synthesis of 4-7 also leads to dimers and small amounts of higher terms (trimers and tetramers).

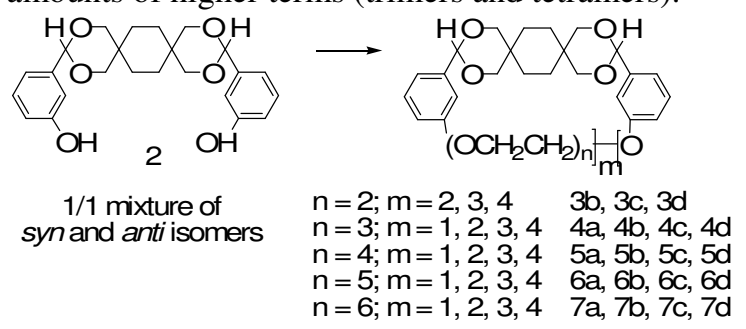

SCHEME 3. Synthesis of macrocycles with dispiro-1,3dioxane units

TABLE 1. Results of the synthesis of compounds 3-7

\begin{tabular}{llll}
\hline Compound & $\mathrm{n}$ & $\begin{array}{l}\text { Yields in } \\
\text { monomer }(\%)^{*}\end{array}$ & $\begin{array}{l}\text { Yields in dimers, } \\
\text { trimers and } \\
\text { tetramers\# }\end{array}$ \\
\hline $\mathbf{3}$ & 2 & - & 61 \\
$\mathbf{4}$ & 3 & 28 & 34 \\
$\mathbf{5}$ & 4 & 32 & 43 \\
$\mathbf{6}$ & 5 & 28 & 50 \\
$\mathbf{7}$ & 6 & 20 & 11 \\
\hline *Calculated taken into account only the amount of syn isomer \\
\#Calculated for the mixture of dimers, trimers and tetramers \\
\multicolumn{3}{l}{ and considering the amount of mixture of syn and anti isomers }
\end{tabular}

These larger macrocycles are obtained by the cyclisation reaction of both syn and anti isomers, with the major participation of the anti isomer of $\mathbf{2}$. For 3 the main products are the dimers and the trimers.

The mixtures of oligomers (from dimers to tetramers) and isomers of $\mathbf{3}$ and $\mathbf{7}$ were subjected to separation (discrimination) by HPLC using a $\mathrm{C}^{18}$ column and water/methanol $=1 / 4$ as elution system. The chromatograms showed high values of the ratios dimers/trimers $(3 \mathbf{b} / \mathbf{3 c}$ : $3.5 / 1$ and $7 \mathbf{b} / 7 \mathbf{c}$ : 6/1) and dimers/tetramers (7b/7d: 19/1). The antianti $(\mathrm{rt}=23.45 \mathrm{~min})$ and the syn-anti $(\mathrm{rt}=22.03$ min) dimers of $\mathbf{7 b}$ (ratio 1/1) could be separated by semipreparative HPLC [the formation of the third possible isomer (syn-syn) was not observed]. Only the syn-syn isomer of dimers of $\mathbf{3}$ could be separated after several crystallizations from the mixture of syn-syn, syn-anti and anti-anti isomers (7/7/1 ratio; determined from the NMR spectrum of the fraction of dimers separated by HPLC). Four isomers are possible for 7c (anti-anti-anti, syn-antianti, syn-syn-anti and syn-syn-syn). Two fractions with trimers $\left(\mathrm{rt}_{1}=30.96 \mathrm{~min}\right.$., $\mathrm{rt}_{2}=32.09 \mathrm{~min}$ in the 
ratio 20/1) were separated (HPLC) for 7c. The NMR spectra showed that the main fraction contains the 1/1 mixture of anti-anti-anti and synanti-anti isomers, while the second fraction mainly exhibits the syn-syn-anti isomer. The formation of the fourth possible trimer could not be observed. The anti-anti dimer of $\mathbf{4 b}$ was isolated by column chromatography (toluene/acetone/ethyl acetate: 4/1/0.5). All the attempts to obtain other pure dimers or trimers failed.

\section{Structural aspects in solid state}

The molecular structures of two monomers (4a and 6a) were obtained by $X$-ray diffractometry. The ORTEP diagrams (Figures 1a and 2a) show the syn orientation of the 1,3-dioxane rings (referred to the central cyclohexane), the equatorial orientation of the aromatic rings located at the extremities of the dispirane skeleton and their peculiar rotameric behavior (intermediary to the usual bisectional $\left[\alpha(\beta)=0^{\circ}\right]$ and orthogonal $\left[\alpha(\beta)=90^{\circ}\right]$ rotamers).

The values of the angles between the aromatic rings and the best planes of the 1,3-dioxane rings for $\mathbf{4 a}$ $\left[\alpha\left(\mathrm{C}^{12} \mathrm{C}^{13} \mathrm{C}^{14} \mathrm{C}^{15} \mathrm{C}^{16} \mathrm{C}^{31} / \mathrm{C}^{21} \mathrm{C}^{20} \mathrm{C}^{34}\right)=33.07^{\circ}\right.$; $\left.\beta\left(\mathrm{C}^{1} \mathrm{C}^{27} \mathrm{C}^{28} \mathrm{C}^{29} \mathrm{C}^{30} \mathrm{C}^{38} / \mathrm{C}^{22} \mathrm{C}^{23} \mathrm{C}^{35}\right)=5.56^{\circ}\right]$ and for 6a $\left[\alpha\left(C^{1} C^{33} C^{34} C^{35} C^{36} C^{44} / C^{28} C^{29} C^{41}\right)=36.18^{\circ} ; \beta\right.$ $\left(\mathrm{C}^{18} \mathrm{C}^{19} \mathrm{C}^{20} \mathrm{C}^{21} \mathrm{C}^{22} \mathrm{C}^{37} / \mathrm{C}^{27} \mathrm{C}^{26} \mathrm{C}^{40}\right)=35.41^{\circ}$ ] show a closer disposition to the bisectional rotamer.

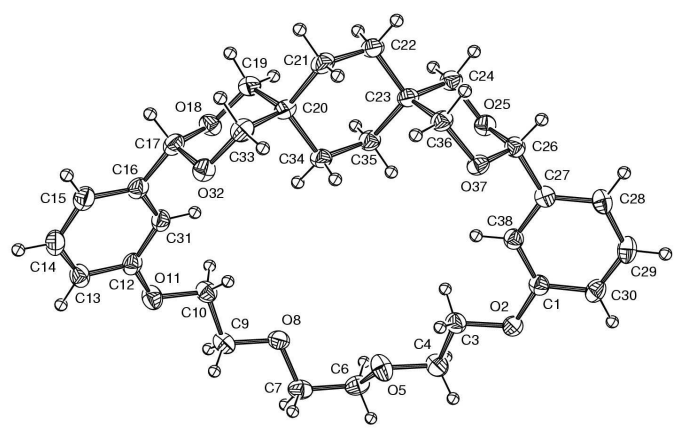

a

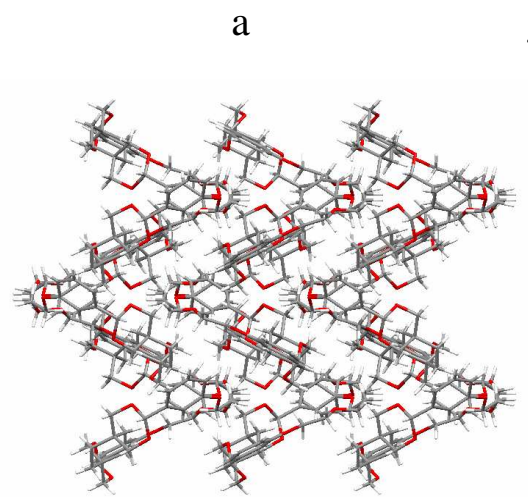

$4 a(A)$

FIGURE 1. Single $\quad c$ tal molecular structure of 4a: ORTEP diagram (a), Mercury representatio.. ... a part of the lattice showing the
The investigations of the lattices showed significant intermolecular $\mathrm{C}-\mathrm{H}-\pi$ interactions between the aromatic rings and the hydrogen atoms of the cyclohexane or of the ethylene oxide units. In the lattice of $\mathbf{4 a}$ the formation of dimers [Figure 1b; molecules $4 \mathbf{a}(\mathrm{A})$ and $4 \mathbf{a}(\mathrm{B})$ ] due to $\mathrm{C}-\mathrm{H}-\pi$ interactions of the aromatic rings $\mathrm{C}^{1} \mathrm{C}^{27} \mathrm{C}^{28} \mathrm{C}^{29} \mathrm{C}^{30} \mathrm{C}^{38}$ with one of the hydrogen atom at $\mathrm{C}^{9}$ (ethylene oxide chain) is observed. The distance from this hydrogen atom to the plane of the aromatic ring is $2.94 \AA$. Each dimer unit exhibits other four $\mathrm{C}-\mathrm{H}-\pi$ interactions with other four dimer units. These interactions involve the $\mathrm{C}^{12} \mathrm{C}^{13} \mathrm{C}^{14} \mathrm{C}^{15} \mathrm{C}^{16} \mathrm{C}^{3}$ type aromatic rings and the equatorial hydrogen atom at $\mathrm{C}^{21}$ (its distance to the plane of the aromatic ring is $2.85 \AA$ ) pertaining to the cyclohexane moieties [only one interaction with molecule $\mathbf{4 a}(\mathrm{C})$ is shown in Figure 1b]. The view along the $\mathrm{c}$ crystallographic axis reveals the interesting zigzag arrangement of the molecules (Figure 1c) The lattice of $\mathbf{6 a}$ (Figure 2b) shows the edge-tilted-to-face arrangement of the different types of aromatic rings pertaining to neighboring molecules. The dihedral angle between these aromatic rings is $83.05^{\circ}$; the distance between the centers of the aromatic rings is $5.27 \AA$ and the distances from $\mathrm{H}^{34}$ and $\mathrm{H}^{35}$ to the plane of the other aromatic ring $\left(\mathrm{C}^{18} \mathrm{C}^{19} \mathrm{C}^{20} \mathrm{C}^{21} \mathrm{C}^{22} \mathrm{C}^{37}\right)$ are 2.85 and $2.98 \AA$ A, respectively. 


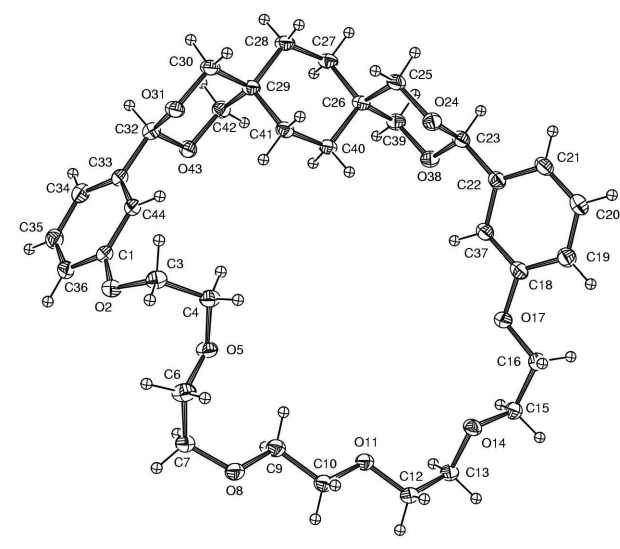

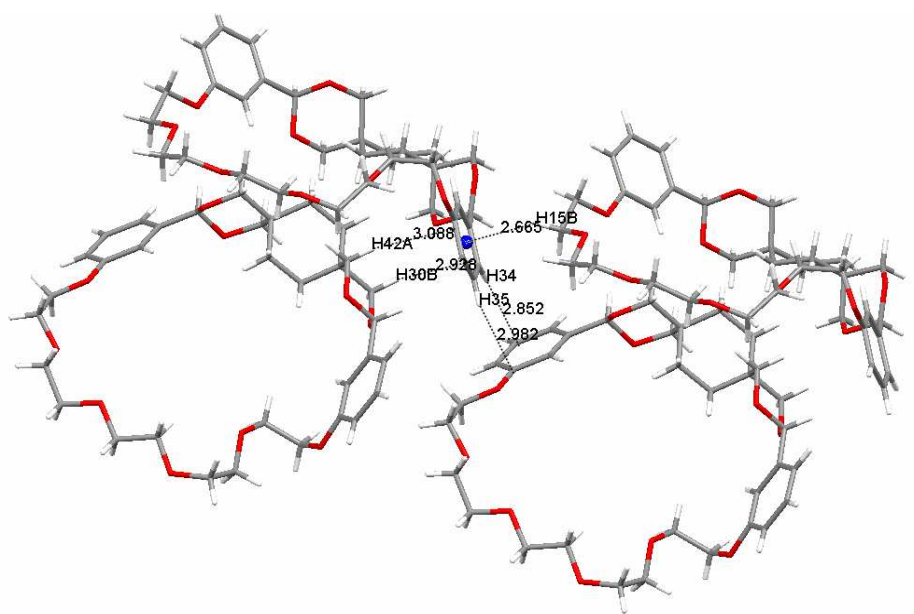

b

FIGURE 2. Single crystal molecular structure of 6a: ORTEP diagram (a) and Mercury representation of a part of the lattice showing the characteristic $\mathrm{CH}-\pi$ interactions (b).

The short distance between the centroid of the aromatic ring $\mathrm{C}^{1} \mathrm{C}^{33} \mathrm{C}^{34} \mathrm{C}^{35} \mathrm{C}^{36} \mathrm{C}^{44}$ and the hydrogen atom at position 15 of a third molecule $(\mathrm{d}=2.66 \AA)$ reflects other important stacking interactions. The same aromatic ring $\mathrm{C}^{1} \mathrm{C}^{33} \mathrm{C}^{34} \mathrm{C}^{35} \mathrm{C}^{36} \mathrm{C}^{44}$ is involves in weaker $\mathrm{C}-\mathrm{H}-\pi$ interactions with the axial hydrogen atoms at positions 30 (distance to the aromatic plane, $\mathrm{d}=2.92 \AA$ ) and 42 (distance to the aromatic plane, $\mathrm{d}$ $=3.08 \AA$ ) of a fourth molecule of macrocycle of the lattice.

\section{Structural aspects in solution}

The NMR investigations of the monomers and dimers at $r t$ (Table 2) show the semiflexible behavior of the dispirane units, with anancomeric 1,3-dioxane rings and flipping cyclohexane units. In ${ }^{1} \mathrm{H}$ NMR spectra, the protons of the 1,3-dioxane rings exhibit different signals (doublets) for the axial and equatorial positions, while the signals of the protons of the cyclohexane ring are two singlets for syn structures and two multiplets for the anti units.

The conformational equilibria of the monomers with syn dispirane units represent enantiomeric inversions

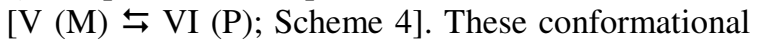
processes were investigated using variable temperature ${ }^{1} \mathrm{H}$ NMR experiments run with compound 4a (Figure 3).

The $r t$ spectrum (toluene- $d_{8}, 600 \mathrm{MHz}$ ) exhibits a doublet for the axial protons of the 1,3-dioxane ring $\left(\delta_{\mathrm{ax}}=3.15 \mathrm{ppm}\right)$ and another doublet for the equatorial protons of the same positions $\left(\delta_{\mathrm{eq}}=3.70\right.$ $\mathrm{ppm}$ ), while the protons of the cyclohexane moiety show two singlets $\left(\delta=0.58, \delta^{\prime}=2.04 \mathrm{ppm}\right)$. The protons of the three ethylene oxide units exhibit 2 multiplets $\left(\delta=4.06, \delta^{\prime}=3.54 \mathrm{ppm}\right)$ and a singlet $(\delta$ $=3.32 \mathrm{ppm}$ ). Lowering the temperature coalescences are observed, and the spectrum at $190 \mathrm{~K}$ shows the frozen structure of the compound. In the frozen structure, the $\mathrm{CH}_{2}$ groups of the 1,3-dioxane are not rendered equivalent anymore by the flipping of the cyclohexane ring. One of these groups is axial and the other one is equatorial with respect to the middle cyclohexane ring and they exhibit different signals in the low temperature NMR spectrum. The low temperature spectrum of $\mathbf{4 a}$ is significantly more complex.

Table 2. NMR data (600 MHz, $\delta$, ppm) for compounds $3 \mathrm{~b}, 4 \mathrm{a}-$ $7 \mathrm{a}, 4 \mathrm{~b}, 6 \mathrm{~b}$ and $7 \mathrm{~b}$

\begin{tabular}{|c|c|c|c|c|c|c|c|}
\hline \multirow[t]{2}{*}{ Compd. } & \multirow[t]{2}{*}{ Solv. } & \multicolumn{2}{|c|}{$\begin{array}{l}1,3- \\
\text { Dioxane } \\
\text { units }\end{array}$} & \multicolumn{4}{|c|}{ Cyclohexane units } \\
\hline & & eq. & ax. & Syn* & & $A n t i^{*}$ & \\
\hline $\begin{array}{l}\mathbf{3 b}(s y n- \\
\text { syn)\# }\end{array}$ & $\mathrm{CDCl}_{3}$ & 4.04 & 3.55 & 1.96 & 1.12 & - & - \\
\hline $4 a$ & Tol. $-d 8$ & 3.70 & 3.14 & 2.05 & 0.59 & - & - \\
\hline $\begin{array}{l}\mathbf{4 b}(\text { anti- } \\
\text { anti) }\end{array}$ & $\mathrm{CDCl}_{3}$ & 3.99 & 3.56 & - & - & 1.76 & 1.22 \\
\hline $5 \mathbf{a}$ & $\mathrm{C}_{6} \mathrm{D}_{6}$ & 3.73 & 3.15 & 1.92 & 0.50 & - & - \\
\hline $6 a$ & $\mathrm{CDCl}_{3}$ & 4.07 & 3.59 & 2.09 & 1.14 & - & - \\
\hline $7 \mathbf{a}$ & $\mathrm{C}_{6} \mathrm{D}_{6}$ & 3.75 & 3.15 & 1.89 & 0.48 & - & - \\
\hline $\begin{array}{l}\mathbf{7 b}(\text { anti- } \\
\text { anti })^{\S}\end{array}$ & $\mathrm{CD}_{2} \mathrm{Cl}_{2}$ & 3.99 & 3.57 & - & - & 1.76 & 1.23 \\
\hline $\begin{array}{l}\text { 7b }(s y n- \\
\text { anti })^{\S}\end{array}$ & $\begin{array}{l}\text { THF- } \\
\mathrm{d} 8\end{array}$ & 4.00 & 3.51 & 1.89 & 1.07 & 1.76 & 1.20 \\
\hline
\end{tabular}

* singlets, **multiplets, ${ }^{*} 500 \mathrm{MHz},{ }^{\S} 400 \mathrm{MHz}$

The assignment of the signals is not possible, but it can be observed that the two doublets recorded at $r t$ for the protons of the 1,3-dioxane moieties and the two triplets recorded for the protons of the bordering ethylene oxide groups are replaced in the low temperature NMR spectrum by 8 groups of signals in the range 3.0-4.2 ppm 
1

2

3

4

5

6

7

8

9

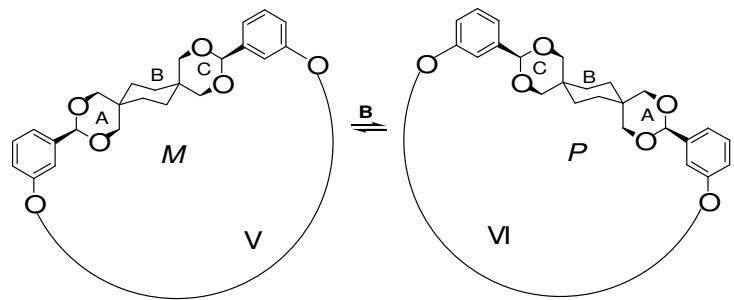

SCHEME 4. Conformational equilibrium for monomers 4a-7a

The flipping of the cyclohexane rings of the anti units in the anti-anti dimers (Scheme 5; VII $\leftrightarrows \mathrm{VIII}$ ) or of the syn units in the syn-syn dimer of $\mathbf{3}$ (simplified representation in Scheme 6; IX $\leftrightarrows \mathrm{X} \leftrightarrows \mathrm{XI}$ ) are diastereoisomeric equilibria.
The chains of the anti-anti dimer macrocycle (Scheme 5) can connect terminal monospirane units with the same configuration in diastereoisomer VIII or of different configurations in diastereoisomer VII. For these dimers (VII and VIII, anti-anti structures) we can consider that the macrocycle exhibits four similar chiral elements (as constitution and as configurations). The possible diastereoisomers are generated by the different positions in the cycle of the chiral elements with the same configurations and they belong to the family of cyclostereoisomers, being cyclodiastereoisomers ${ }^{44}$ (Scheme 5).

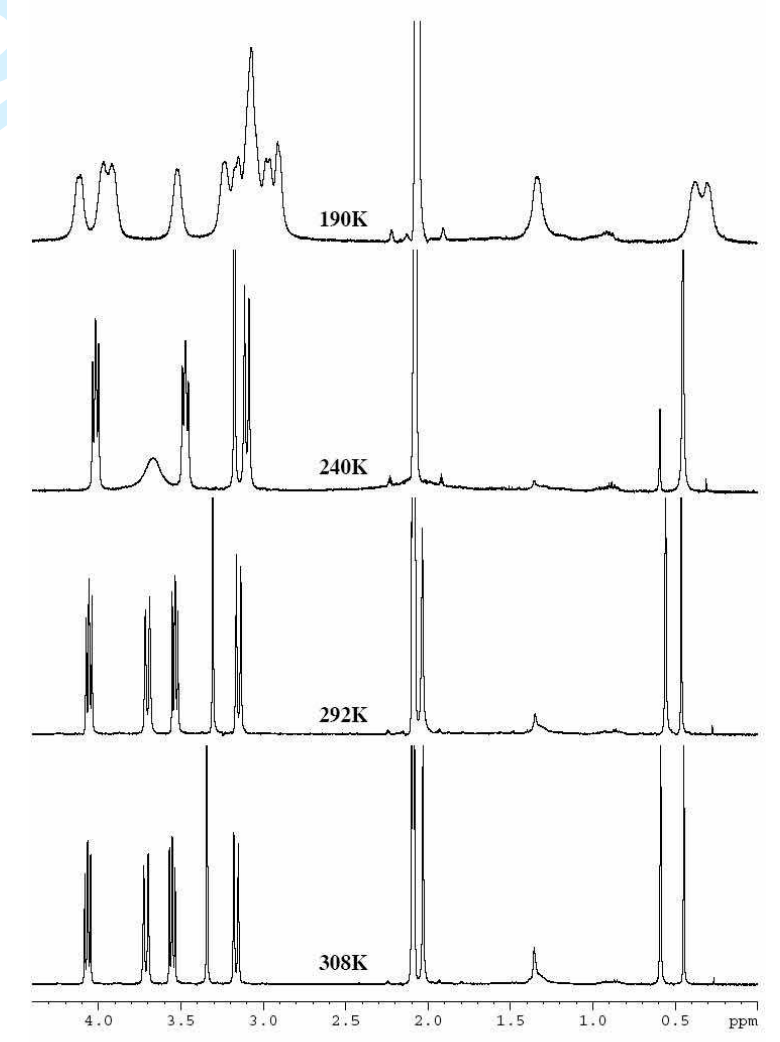

FIGURE 3. Variable NMR spectra run with compound 4 a.

The flipping of one of the cyclohexane rings ( $\mathrm{B}$ or B') transforms one diastereoisomer into the other. The flipping of the middle ring in the syn-syn dimer 3b equilibrates like (IX, XI) and unlike (X) structures (Scheme 6).

The variable temperature ${ }^{1} \mathrm{H}$ NMR experiments $\left(\mathrm{CD}_{2} \mathrm{Cl}_{2}\right)$ performed with the anti-anti isomer of $\mathbf{7 b}$ showed important modifications of the signals pertaining to the methylene protons of the 1,3dioxane rings and of those of the cyclohexane rings. At $r t$ the spectrum exhibits two doublets $\left(\delta_{\text {eq }}=3.99\right.$ and $\left.\delta_{\mathrm{ax}}=3.57 \mathrm{ppm}\right)$ for the protons of the 1,3dioxane rings and two multiplets $\left(\delta=1.23\right.$ and $\delta^{\prime}=$ $1.76 \mathrm{ppm}$ ) for the protons of the cyclohexane rings. At low temperature the spectra of the frozen structure are complicated because they exhibit the signals of two frozen diastereoisomers (VII and VIII) and because the $\mathrm{CH}_{2}$ groups of the same 1,3-dioxane cycle are not equivalent anymore (one of the groups is equatorial and the other one is axial as referred to the neighboring cycle). The signals of the dispirane units begin to modify at $250 \mathrm{~K}$ and at $220 \mathrm{~K}$ they are 
practically completely incorporated in the base line. The signals reappear (at different chemical shifts) at $200 \mathrm{~K}$ and at $190 \mathrm{~K}$ (the lowest temperature reached in this experiment) and one can observe two groups of signals (unsolved) for the protons of the 1,3- dioxane rings in the ranges 3.4-3.7 ppm and 4.2-4.3 ppm and other two groups of signals in the ranges 0.8-1.05 ppm and 2.15-2.2 ppm for the protons of the cyclohexane rings

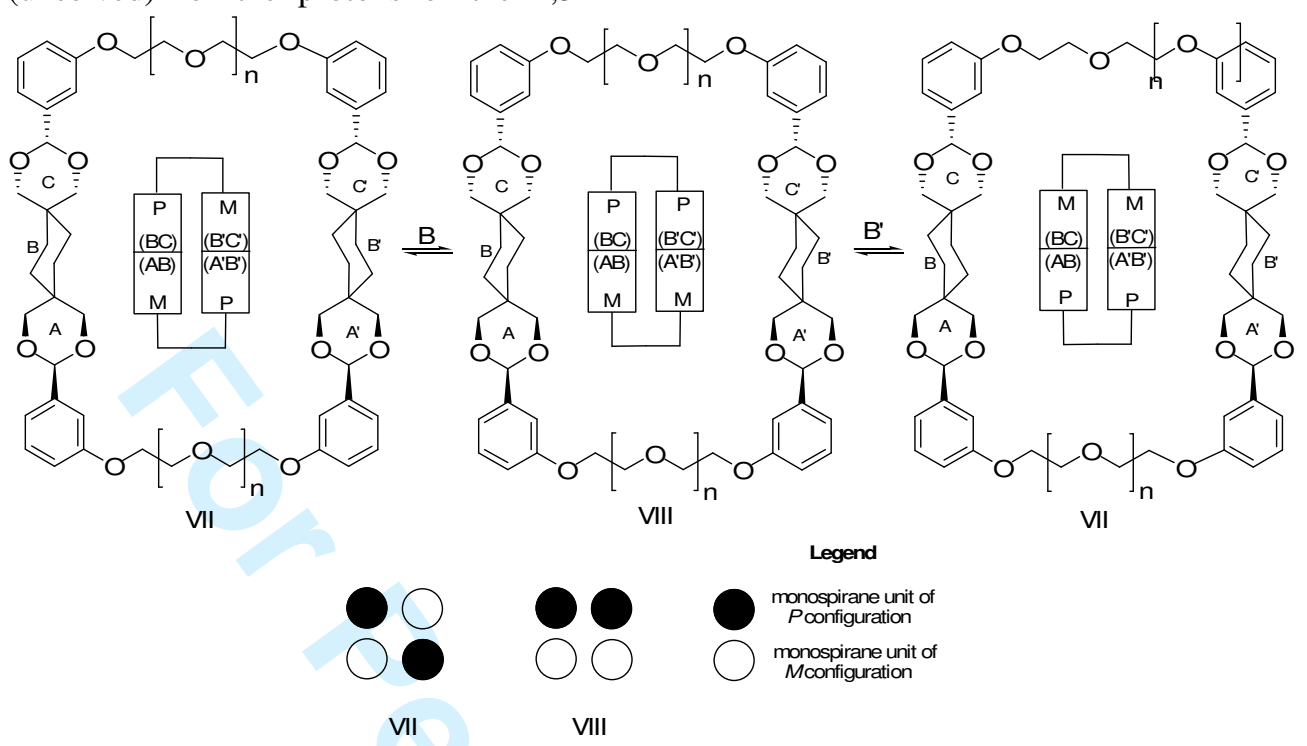

SCHEME 5. Conformational equilibria involving the cyclodiastereoisomers of the anti-anti dimers.

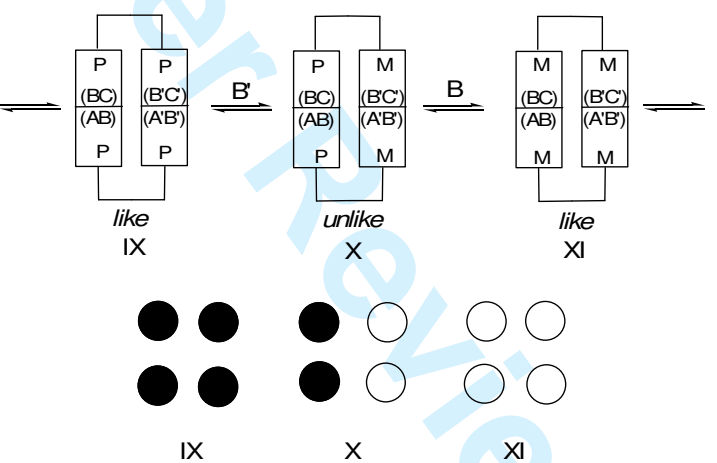

SCHEME 6. Representation of the conformational equilibria involving the like and unlike diastereoisomers of the syn-syn

\section{CONCLUSIONS}

The synthesis of macrocycles containing dispiro-1,3dioxane units was carried out starting from dispiranes with phenol groups and from ditosylated polyethylene glycols. The monomers were obtained only by the enclosure in the macrocycles of the syn dispirane isomers, while the higher terms (dimers, trimers....) were obtained with the participation of both syn and anti dispiranes. The structural analysis using variable temperature NMR experiments revealed the flipping of the central cyclohexane ring of the dispirane units inside the macrocycle having as result enantiomeric inversions for monomers and diastereoisomeric equilibria for dimers.

\section{EXPERIMENTAL PART}

NMR spectra $\left[{ }^{1} \mathrm{H}(600,500\right.$ or $400 \mathrm{MHz}),{ }^{13} \mathrm{C}(150$,
125, or $100 \mathrm{MHz}$ ), COSY, APT, HETCOR (HMBC, HMQC), NOESY or ROESY] were recorded at $\mathrm{rt}$, in $\mathrm{CDCl}_{3}, \mathrm{C}_{6} \mathrm{D}_{6}$, Tol.- $d_{8}, \mathrm{CD}_{2} \mathrm{Cl}_{2}$, THF- $d_{8}$. Melting points are uncorrected. Microanalyses $(\mathrm{C}, \mathrm{H})$ agreed with calculated data. FAB and MALDI ${ }^{+}$spectra were obtained on a JEOL JMS AX-500 spectrometer under usual conditions. X-ray crystallographic data for 4a and 6a are deposited CCDC-239963(4a) and CCDC-255760 (6a) at Cambridge Crystallographic Data Centre, 12, Union Road, Cambridge CB2 1EZ, UK; fax: (internat. +44-1223/336-003; e-mail: deposit@ccdc.cam.ac.uk and they can be obtained free of charge at http:// www.ccdc.cam.ac. uk/conts/retrieving.html.

The structural (crystallographic) data were collected on a NONIUS Kappa CCD diffractometer with graphite monochromatized $\mathrm{MoK}_{\alpha}$ radiation. ${ }^{45}$ The cell parameters are obtained with Denzo and Scalepack $^{46}$ with 10 frames $\left(\psi\right.$ rotation : $1^{\circ}$ per 
frame). The structure was solved with SIR- $97^{47}$ which reveals the non hydrogen atoms of the compounds. After anisotropic refinement, many hydrogen atoms may be found with a Fourier Difference. The whole structure was refined with SHELXL97 $7^{48}$ by the fullmatrix least-square techniques. Atomic scattering factors from International Tables for X-ray Crystallography. ${ }^{49}$ Ortep views realized with PLATON98 ${ }^{50}$ The parameters of the crystals and of the determinations are given in Table 3.

TABLE 3. Details of the X-ray diffractometry molecular structure determinations.

\begin{tabular}{|c|c|c|}
\hline Parameterslcompound & $4 \mathbf{a}$ & $6 \mathbf{6}$ \\
\hline Empirical formula & $\mathrm{C}_{30} \mathrm{H}_{38} \mathrm{O}_{8}$ & $\mathrm{C}_{34} \mathrm{H}_{46} \mathrm{O}_{10}$ \\
\hline Formula weight & 526.60 & 614.71 \\
\hline Temperture (K) & 130 & $120(1)$ \\
\hline Wavelength (A) & 0.71069 & 0.71069 \\
\hline Crystal system & orthorhombic & monoclinic \\
\hline Space group & Pbca & $\mathrm{P} 21 / \mathrm{a}$ \\
\hline \multicolumn{3}{|l|}{ Unit cell dimensions } \\
\hline $\mathrm{a}(\AA)$ & $16.0200(2)$ & $12.0158(3)$ \\
\hline $\mathrm{b}(\AA)$ & $12.1790(1)$ & $18.5170(4)$ \\
\hline$c(\AA)$ & $28.1491(3)$ & $15.0221(3)$ \\
\hline$\alpha\left(^{\circ}\right)$ & 90 & 90 \\
\hline$\beta\left(^{\circ}\right)$ & 90 & $109.3560(10)$ \\
\hline$\gamma\left({ }^{\circ}\right)$ & 90 & 90 \\
\hline Volume $\left(\AA^{3}\right)$ & $5492.1(1)$ & $3153.45(12)$ \\
\hline $\mathrm{Z}$ & 8 & 4 \\
\hline Density (calc.) $\left(\mathrm{mg} / \mathrm{m}^{-3}\right)$ & 1.274 & 1.295 \\
\hline $\begin{array}{l}\text { Absorption } \\
\text { coefficient }\left(\mathrm{mm}^{-1}\right)\end{array}$ & 0.092 & 0.094 \\
\hline $\mathrm{F}(000)$ & 2256 & 1320 \\
\hline \multirow{2}{*}{ Crystal size(mm) } & $0.45 * 0.32 * 0.30$ & $0.35 \times 0.35 \times$ \\
\hline & $\mathrm{mm}$ & $0.08 \mathrm{~mm}$ \\
\hline Reflections collected & 6284 & 7210 \\
\hline Independent reflections & $\begin{array}{l}6284[\text { R(int })= \\
0.0000]\end{array}$ & $\begin{array}{l}7210[\mathrm{R}(\text { int })= \\
0.0000]\end{array}$ \\
\hline \multirow{2}{*}{$\begin{array}{l}\text { Reflections observed } \\
\text { Data / restraints / } \\
\text { parameters }\end{array}$} & 4641 & 5774 \\
\hline & $6284 / 0 / 344$ & $7210 / 0 / 398$ \\
\hline Final $R$ indices $\left[\mathrm{F}^{2}>2 \sigma\left(\mathrm{F}^{2}\right)\right]$ & $\begin{array}{l}\mathrm{R}_{1}=0.0475 \\
\mathrm{wR}_{2}=0.1330\end{array}$ & $\begin{array}{l}\mathrm{R}_{1}=0.0499 \\
\mathrm{wR}_{2}=0.1297\end{array}$ \\
\hline $\mathrm{R}$ indices (all data) & $\begin{array}{l}\mathrm{R}_{1}=0.0716 \\
\mathrm{wR}_{2}=0.1530\end{array}$ & $\begin{array}{l}\mathrm{R}_{1}=0.0655 \\
\mathrm{wR}_{2}=0.1429\end{array}$ \\
\hline
\end{tabular}

Analytical HPLC was performed on a Thermo Separation Products (Courtaboeuf, France) P4000 Liquid Chromatograph pump coupled to a Thermo Separation Products (Courtaboeuf, France) UV 200 detector. Data were collected by Chromquest 2.51 software from Thermoquest Corporation. Analytical column was a HyPURITY ${ }^{\circledR} \mathrm{Cl} 8(125 \mathrm{~mm} \times 4 \mathrm{~mm}$; $5 \mu \mathrm{m})$ purchased from Thermo Hypersil (Courtaboeuf, France). Semi-preparative purification was performed on a Varian 9010 HPLC pump coupled to a Varian 9050 UV detector. The chromatographic column was a Nucleosil C18 $(250 \mathrm{~mm} \times 10 \mathrm{~mm} ; 5 \mu \mathrm{m})$ from Interchim (Monluçon, France). Separations were carried out at room temperature in gradient elution mode $\left(\mathrm{H}_{2} \mathrm{O}: \mathrm{MeOH} 20: 80\right.$ to $0: 100$ in $\left.30 \mathrm{~min}\right)$ at $4 \mathrm{~mL} / \mathrm{min}$. Solutions of crude mixture were prepared in THF at a concentration of $5 \mathrm{~g} / \mathrm{L}$ for analytical chromatography and $50 \mathrm{~g} / \mathrm{L}$ for semi-preparative chromatography. The fractions collected by semipreparative chromatography were evaporated to dryness under vacuum. All solvents were of HPLC grade and were purchased from VWR (Fontenaysous-Bois, France).

\section{Procedure for the synthesis of 2}

The meta-hydroxybenzaldehyde $(44 \mathrm{mmol})$ and $0.2 \mathrm{~g}$ of $p$-toluenesulphonic acid were added to a solution of $15 \mathrm{mmol}$ 1,1,4,4-tetrahydroxymethylcyclohexane in $200 \mathrm{ml}$ toluene. The mixture was refluxed and the water resulting from the reaction was removed using a Dean-Stark trap. After the theoretical amount of water was separated, the reaction mixture was cooled at room temperature and the catalyst was neutralized (under stirring) with powdered $\mathrm{CH}_{3} \mathrm{COONa}$ in excess $(0.4 \mathrm{~g})$. The reaction mixture was washed twice with $100 \mathrm{ml}$ water. The organic layer was dried over $\mathrm{Na}_{2} \mathrm{SO}_{4}$, then the toluene was removed under reduced pressure and the crude dispiro compound was subjected to flash chromatography $($ pentane/acetone $=3 / 1)$.

\section{General procedure for the synthesis of 3-7}

Dispirane $2(4.8 \mathrm{mmol})$ and $24 \mathrm{mmol} \mathrm{Cs}_{2} \mathrm{CO}_{3}$ in 0.91 acetonitrile have been refluxed for $12 \mathrm{~h}$. To the obtained suspension, under refluxing solvent, 4.8 mmol of ditosylated polyethyleneglycol dissolved in 0.11 acetonitrile have been added during 4 days using a syringe pump. The reflux of the solvent has been continued for one more day. The system was brought to $\mathrm{rt}$ and the solid phase was removed by filtration. The acetonitrile was evaporated and the crude product was dissolved in $300 \mathrm{ml} \mathrm{CH}_{2} \mathrm{Cl}_{2}$ and then washed with $2 \times 100 \mathrm{ml}$ solution of $\mathrm{KOH} 2 \%$ and $2 \times 100 \mathrm{ml}$ of water. After drying $\left(\mathrm{Na}_{2} \mathrm{SO}_{4}\right)$ the solvent was removed and the crude product was subjected to flash chromatography.

\section{$\mathbf{2 , 5 , 8 , 1 5 , 2 2 , 2 9 , 3 2 , 3 5 , 4 2 , 4 9 , 5 6 , 6 1 , 6 4 , 6 9 - t e t r a d e c a}$} oxaundecacyclo $\left[49 \cdot 3 \cdot 2^{14,17} \cdot 2^{17,20} \cdot 2^{20,23} \cdot 2^{41,44} \cdot 2^{44,47}\right.$. $\left.2^{47,50} \cdot 1^{1,51} \cdot 1^{9,13} \cdot 1^{24,28} \cdot 1^{36,40}\right]$ heptaconta-9,11,24,26,36, 38,51,53,1(70),55,62,63-dodecaene (3b). White solid, mp $254-256{ }^{\circ} \mathrm{C}$, several crystallisation from ethylacetate, $16.0 \%$ yield. $\delta_{\mathrm{H}}\left(500 \mathrm{MHz}, \mathrm{CDCl}_{3}\right)$ 1.12, 1.96 (s, 16H, 18-H, 19-H, 45-H, 46-H, 58-H, $59-\mathrm{H}, 66-\mathrm{H}, 67-\mathrm{H}), 3.55$ (d, $J=11.3 \mathrm{~Hz}, 8 \mathrm{H}, 16-\mathrm{H}_{\mathrm{ax}}$, $21-\mathrm{H}_{\mathrm{ax}}, 43-\mathrm{H}_{\mathrm{ax}}, 48-\mathrm{H}_{\mathrm{ax}}, 57-\mathrm{H}_{\mathrm{ax}}, 60-\mathrm{H}_{\mathrm{ax}}, 65-\mathrm{H}_{\mathrm{ax}}, 68-$ $\mathrm{H}_{\mathrm{ax}}$ ), $3.92(\mathrm{t}, J=4.9 \mathrm{~Hz}, 8 \mathrm{H}, 4-\mathrm{H}, 6-\mathrm{H}, 31-\mathrm{H}, 33-\mathrm{H})$, $4.04\left(\mathrm{~d}, J=11.3 \mathrm{~Hz}, 8 \mathrm{H}, 16-\mathrm{H}_{\mathrm{eq}}, 21-\mathrm{H}_{\mathrm{eq}}, 43-\mathrm{H}_{\mathrm{eq}}, 48-\right.$ $\left.\mathrm{H}_{\text {eq }}, 57-\mathrm{H}_{\text {eq }}, 60-\mathrm{H}_{\text {eq }}, 65-\mathrm{H}_{\text {eq }}, 68-\mathrm{H}_{\text {eq }}\right), 4.18(\mathrm{t}, J=4.9$ $\mathrm{Hz}, 3-\mathrm{H}, 7-\mathrm{H}, 30-\mathrm{H}, 34-\mathrm{H}), 5.37$ (s, 14-H, 23-H, 41$\mathrm{H}, 50-\mathrm{H}), 6.90(\mathrm{dd}, J=8.2,2.7 \mathrm{~Hz}, 4 \mathrm{H}, 10-\mathrm{H}, 27-\mathrm{H}$, 37-H, 54-H), 6.98 (d, J=7.5 Hz, 4H, 11-H, 26-H, 38$\mathrm{H}, 53-\mathrm{H}$ ), 7.17 (overlapped peaks, 4H, 12-H, 25-H, 
39-H, 52-H), 7.24 (overlapped peaks, 4H, 55-H, 62$\mathrm{H}, 63-\mathrm{H}, 70-\mathrm{H}) ; \delta_{\mathrm{C}}\left(125 \mathrm{MHz}, \mathrm{CDCl}_{3}\right) 25.93,26.67$ (18-C, 19-C, 45-C, 46-C, 58-C, 59-C, 67-C, 66-C), 32.87 (17-C, 20-C, 44-C, 47-C), 67.95 (3-C, 7-C, 30C, 34-C), 70.22 (4-C, 6-C, 31-C, 33-C), 75.42 (16-C, 21-C, 43-C, 48-C, 57-C, 60-C, 65-C, 68-C), 102.08 (14-C, 23-C, 41-C, 50-C), 112.16 (55-C, 62-C, 63-C, 70-C), 116.09 (10-C, 27-C, 37-C, 54-C), 119.38 (11C, 26-C, 38-C, 53-C), 129.33 (12-C, 25-C, 39-C, 52C), 140.18 (13-C, 24-C, 40-C, 51-C), 159.28 (1-C, 9C, 28-C, 36-C). $\mathrm{FD}^{+}: \mathrm{m} / \mathrm{z}: 965.7[\mathrm{M}+\mathrm{H}]^{+}$. $\mathrm{C}_{56} \mathrm{H}_{68} \mathrm{O}_{14}$ requires: $\mathrm{C}, 69.69 ; \mathrm{H}, 7.10 \%$ : found: $\mathrm{C}, 69.51 ; \mathrm{H}$, $7.27 \%$.

$2,5,8,11,18,25,32,37-o c t a o x a h e x a c y c l o\left[25.3 .2^{17,20}\right.$. $\left.2^{20,23} \cdot 2^{23,26} \cdot 1^{1,27} \cdot 1^{12,16}\right]$ octatriaconta-1(38),12,14,

16(31),27,29-hexaene (4a). White solid, mp 194.5$195{ }^{\circ} \mathrm{C}$, column chromatography, (dichloromethane/pentane/ethylacetate $\left.=4 / 1 / 0.5 ; \quad R_{\mathrm{f}}=0.29\right)$ $14.0 \%$ yield. $\delta_{\mathrm{H}}(600 \mathrm{MHz}, \mathrm{Tol}-d 8) 0.15(\mathrm{~s}, 4 \mathrm{H}, 21-$ $\mathrm{H}, 22-\mathrm{H}$ ), 2.13 (s, 4H, 34-H, 35-H), 3.28 (d, J=10.8 $\left.\mathrm{Hz}, 4 \mathrm{H}, 19-\mathrm{H}_{\mathrm{ax}}, 24-\mathrm{H}_{\mathrm{ax}}, 33-\mathrm{H}_{\mathrm{ax}}, 36-\mathrm{H}_{\mathrm{ax}}\right) 3.33$ (s, 4H, 6-H, 7-H, $3.55(\mathrm{t}, J=7.2 \mathrm{~Hz}, 4 \mathrm{H}, 4-\mathrm{H}, 9-\mathrm{H}) 3.71(\mathrm{~d}$, $\left.J=10.8 \mathrm{~Hz}, 4 \mathrm{H}, 19-\mathrm{H}_{\mathrm{eq}}, 24-\mathrm{H}_{\mathrm{eq}}, 36-\mathrm{H}_{\mathrm{eq}}, 33-\mathrm{H}_{\mathrm{eq}}\right) 4.13$ (t, $J=7.2 \mathrm{~Hz}, 4 \mathrm{H}, 3-\mathrm{H}, 10-\mathrm{H}) 5.32(\mathrm{~s}, 2 \mathrm{H}, 17-\mathrm{H}, 26-$ H) 6.83 (overlapped peaks, 2H, 15- H, 28-H), 6.92 (overlapped peaks, $2 \mathrm{H}, \quad 13-\mathrm{H}, \quad 30-\mathrm{H}$ ), 7.15 (overlapped peaks, 2H, 14-H, 29-H) 7.69 (overlapped peaks, $2 \mathrm{H}, 31-\mathrm{H}, 38-\mathrm{H}) ; \delta_{\mathrm{C}}(150 \mathrm{MHz}$, Tol- $d 8) 25.74$ (21-C, 22-C) 25.76 (34-C, 35-C), 33.14 (20-C, 23-C), 66.48 (3-C, 10-C), 69.05 (4-C, 9-C) 70.96 (6-C, 7-C) 74.47 (19-C, 24-C, 36-C, 33C) 102.16 (17-C, 26-C) 111.35 (31-C, 38-C) 118.27 (13-C, 30-C ) 119.79 (15-C, 28-C) 128.65 (14-C, 29C) 141.71 (16-C, 27-C) 159.69 (12-C, 1-C). MALDITOF, m/z:=549.2 $[\mathrm{M}+\mathrm{Na}]^{+} ; 565.5[\mathrm{M}+\mathrm{K}]^{+} ; 658.6$ $[\mathrm{M}+\mathrm{Cs}]^{+} . \mathrm{C}_{30} \mathrm{H}_{38} \mathrm{O}_{8}$ requires: $\mathrm{C}, 68.42 ; \mathrm{H}, 7.28 \%$; found: $\mathrm{C}, 68.47 ; \mathrm{H}, 7.33 \%$

$\mathbf{2 , 5 , 8 , 1 1 , 1 8 , 2 5 , 3 2 , 3 5 , 3 8 , 4 1 , 4 8 , 5 5 , 6 2 , 6 7 , 7 0 , 7 5 h e x a d e}$ caoxaundecacyclo $\left[55.3 .2^{17,20} \cdot 2^{20,23} \cdot 2^{23,26} \cdot 2^{47,50} \cdot 2^{50,53}\right.$. $\left.2^{53,56} \cdot 1^{1,57} \cdot 1^{12,16} \cdot 1^{27,31} \cdot 1^{42,46}\right]$ hexaheptaconta-12,14, 27,29,42,44,57, 59,61,68,69,76(1)-dodecaene (4b). White solid, mp 183-184 ${ }^{\circ} \mathrm{C}$, column chromatography, (toluene/acetone/ethyl acetate = $\left.4 / 1 / 0.5 ; R_{\mathrm{f}}=0.21\right) 14 \%$ yield. $\delta_{\mathrm{H}}(600 \mathrm{MHz}$, Tol- $d 8)$ $1.22(\mathrm{t}, J=6.6 \mathrm{~Hz}, 8 \mathrm{H}, 21-\mathrm{H}, 65-\mathrm{H}, 51-\mathrm{H}, 73-\mathrm{H}), 1.76$ (t, $J=6.6 \mathrm{~Hz}, 8 \mathrm{H}, 22-\mathrm{H}, 64-\mathrm{H}, 52-\mathrm{H}, 72-\mathrm{H}), 3.56$ (d, $J=11.4 \mathrm{~Hz}, 8 \mathrm{H}, 19-\mathrm{H}_{\mathrm{ax}}, 24-\mathrm{H}_{\mathrm{ax}}, 49-\mathrm{H}_{\mathrm{ax}}, 54-\mathrm{H}_{\mathrm{ax}}, 63-$ $\left.\mathrm{H}_{\mathrm{ax}}, 66-\mathrm{H}_{\mathrm{ax}}, 71-\mathrm{H}_{\mathrm{ax}}, 74-\mathrm{H}_{\mathrm{ax}}\right), 3.70(\mathrm{~s}, 8 \mathrm{H}, 6-\mathrm{H}, 7-\mathrm{H}$, 36-H, 37-H), 3.82 (t, J=4.8 Hz, 8H, 4-H, 9-H, 34-H, $39-\mathrm{H}), 3.99\left(\mathrm{~d}, J=11.4 \mathrm{~Hz}, 8 \mathrm{H}, 19-\mathrm{H}_{\mathrm{eq}}, 24-\mathrm{H}_{\mathrm{eq}}, 49-\right.$ $\left.\mathrm{H}_{\mathrm{eq}}, 54-\mathrm{H}_{\mathrm{eq}}, 63-\mathrm{H}_{\mathrm{eq}}, 66-\mathrm{H}_{\mathrm{eq}}, 71-\mathrm{H}_{\mathrm{eq}}, 74-\mathrm{H}_{\mathrm{eq}}\right), 4.10(\mathrm{t}$, $J=4.8 \mathrm{~Hz}, 8 \mathrm{H}, 3-\mathrm{H}, 10-\mathrm{H}, 33-\mathrm{H}, 40-\mathrm{H}), 5.32(\mathrm{~s}, 4 \mathrm{H}$, 17-H, 26-H, 47-H, 56-H), 6.85 (ddd, $J=1.8,2.4,7.2$ $\mathrm{Hz}, 4 \mathrm{H}, 13-\mathrm{H}, 30-\mathrm{H}, 43-\mathrm{H}, 60-\mathrm{H}), 7.01$ (d, $J=7.8 \mathrm{~Hz}$, $4 \mathrm{H}, 15-\mathrm{H}, 28-\mathrm{H}, 45-\mathrm{H}, 58-\mathrm{H}$ ), 7.04 (overlapped peaks, $4 \mathrm{H}, 61-\mathrm{H}, 68-\mathrm{H}, 69-\mathrm{H}, 76-\mathrm{H}), 7.21$ (t, $J=7.8$ $\mathrm{Hz}, 4 \mathrm{H}, 14-\mathrm{H}, 29-\mathrm{H}, 44-\mathrm{H}, 59-\mathrm{H}) ; \delta_{\mathrm{C}}(150 \mathrm{MHz}$, Tol- $d 8)$ 25.47, 26.92 (21-C, 22-C, 51-C, 52-C, 64-C,
65-C, 72-C, 73-C), 32.91 (20-C, 23-C, 50-C, 53-C), 67.69 (3-C, 10-C, 33-C, 40-C), 70.05 (4-C, 9-C, 34C, 39-C), 71.20 (6-C, 7-C, 36-C, 37-C), 75.48 (19-C, 24-C, 49-C, 54-C, 63-C, 66-C, 71-C, 74-C), 102.16 (17-C, 26-C, 47-C, 56-C), 112.27 (61-C, 68-C, 69-C, 76-C), 115.86 (13-C, 30-C, 43-C, 60-C), 118.88 (15C, 28-C, 45-C, 58-C), 129.58 (14-C, 29-C, 44-C, 59C), 140.03 (16-C, 27-C, 46-C, 57-C), 159.08 (12-C, 31-C, 42-C, 1-C). MALDI-TOF, $\mathrm{m} / \mathrm{z}=1075.5$ $[\mathrm{M}+\mathrm{Na}]^{+}, 1091.5[\mathrm{M}+\mathrm{K}]^{+} . \mathrm{C}_{60} \mathrm{H}_{76} \mathrm{O}_{16}$ requires: $\mathrm{C}$, 68.42 ; H, 7.28\%; found: C, $68.55 ; \mathrm{H}, 7.39 \%$.

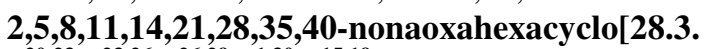
$\left.2^{20,23} \cdot 2^{23,26} \cdot 2^{26,29} \cdot 1^{1,30} \cdot 1^{15,19}\right]$ hentetraconta-1(41),15, 17,19(34), 30(31),32-hexaene (5a). White solid, mp $182-183{ }^{\circ} \mathrm{C}$, column chromatography, (dichloromethane/ethylacetate $\left.=3 / 7 ; R_{\mathrm{f}}=0.35\right) \quad 16.0 \%$ yield. $\delta_{\mathrm{H}}$ $\left(600 \mathrm{MHz}, \mathrm{C}_{6} \mathrm{D}_{6}\right) 0.5(\mathrm{~s}, 4 \mathrm{H}, 24-\mathrm{H}, 25-\mathrm{H}), 1.92(\mathrm{~s}$, $4 \mathrm{H}, 37-\mathrm{H}, 38-\mathrm{H}$ ), 3.15 (d, J=10.8 Hz, 4H, 22- $\mathrm{H}_{\mathrm{ax}}, 27-$ $\left.\mathrm{H}_{\mathrm{ax}}, 36-\mathrm{H}_{\mathrm{ax}}, 39-\mathrm{H}_{\mathrm{ax}}\right), 3.38$ (s, 8H, 6- H, 7-H, 9-H, 10$\mathrm{H}), 3.51(\mathrm{t}, J=6 \mathrm{~Hz}, 4 \mathrm{H}, 4-\mathrm{H}, 12-\mathrm{H}), 3.73(\mathrm{~d}, J=10.8$ $\left.\mathrm{Hz}, 4 \mathrm{H}, 22-\mathrm{H}_{\mathrm{eq}}, 27-\mathrm{H}_{\mathrm{eq}}, 36-\mathrm{H}_{\mathrm{eq}}, 39-\mathrm{H}_{\mathrm{eq}}\right), 3.91$ (t, $J=6$ $\mathrm{Hz}, 4 \mathrm{H}, 3-\mathrm{H}, 13-\mathrm{H}), 5.35$ (s, 2H, 20-H, 29-H), 6.93 (dd, $J=8.4,10.8 \mathrm{~Hz}, 2 \mathrm{H}, 16-\mathrm{H}, 33-\mathrm{H}), 6.94$ (d, $J=6.6$ $\mathrm{Hz}, 2 \mathrm{H}, 18-\mathrm{H}, 31-\mathrm{H}), 7.08$ (t, $J=7.8 \mathrm{~Hz}, 2 \mathrm{H}, 17-\mathrm{H}$, $32-\mathrm{H}), 7.71(\mathrm{~d}, J=1.2 \mathrm{~Hz}, 2 \mathrm{H}, 34-\mathrm{H}, 41-\mathrm{H}) ; \delta_{\mathrm{C}}(150$ $\mathrm{MHz}, \mathrm{C}_{6} \mathrm{D}_{6}$ ) 26.24 (37-C, 38-C), 26.44 (24-C, 25-C), 33.38 (23-C, 26-C), 67.61 (3-C, 13-C), 70.29 (4-C, 12-C), 71.53, 71.74 (6-C, 7-C, 9-C, 10-C), 75.39 (22C, 27-C, 36-C, 39-C), 103.14 (20-C, 29-C), 112.28 (34-C, 41-C), 117.93 (16-C, 33-C), 120.58 (18-C, 31-C), 129.61 (17-C, 32-C), 141.97 (19-C, 30-C), 160.39 (1-C, 15-C). FAB, m/z=571.0 [M+H] ${ }^{+}$. $\mathrm{C}_{30} \mathrm{H}_{38} \mathrm{O}_{8}$ requires: $\mathrm{C}, 67.35 ; \mathrm{H}, 7.42 \%$; found: $\mathrm{C}$, $67.55 ; \mathrm{H}, 7.61 \%$.

2,5,8,11,14,17,24,31,38,43-decaoxahexacyclo[31.3. $\left.2^{23,26} \cdot 2^{26,29} \cdot 2^{29,32} \cdot 1^{1,33} \cdot 1^{18,22}\right]$ tetratetraconta-1(44), 18,20,22 (37),33,35-hexaene (6a). White solid, mp $167-168{ }^{\circ} \mathrm{C}$, column chromatography, (toluene/ acetone/ethylacetate $\left.=4 / 1 / 0.2 ; R_{\mathrm{f}}=0.26\right) 14.0 \%$ yield. $\delta_{\mathrm{H}}\left(600 \mathrm{MHz}, \mathrm{CDCl}_{3}\right) 1.14(\mathrm{~s}, 4 \mathrm{H}, 40-\mathrm{H}, 41-\mathrm{H}), 2.09$ (s, 4H, 27-H, 28-H), 3.59 (d, J=12 Hz, 4H, 25- $\mathrm{H}_{\mathrm{ax}}$, $\left.30-\mathrm{H}_{\mathrm{ax}}, 42-\mathrm{H}_{\mathrm{ax}}, 39-\mathrm{H}_{\mathrm{ax}}\right), 3.70(\mathrm{~s}, 4 \mathrm{H}, 9-\mathrm{H}, 10-\mathrm{H})$, 3.70-3.72 (overlapped peaks, 4H, 7-H, 12-H), 3.743.76 (overlapped peaks, 4H, 6- $\mathrm{H}, 13-\mathrm{H}), 3.88(\mathrm{t}$, $J=5.4 \mathrm{~Hz}, 4 \mathrm{H}, 4-\mathrm{H}, 15-\mathrm{H}), 4.07$ (d, $J=12 \mathrm{~Hz}, 4 \mathrm{H}, 25-$ $\left.\mathrm{H}_{\mathrm{eq}}, 30-\mathrm{H}_{\mathrm{eq}}, 42-\mathrm{H}_{\mathrm{eq}}, 39-\mathrm{H}_{\mathrm{eq}}\right), 4.19(\mathrm{t}, J=5.4 \mathrm{~Hz}, 4 \mathrm{H}$, $3-\mathrm{H}, 16-\mathrm{H}), 5.40(\mathrm{~s}, 2 \mathrm{H}, 23-\mathrm{H}, 32-\mathrm{H}), 6.90-6.91$ (overlapped peaks, 2H, 21-H, 34-H), 6.91-6.92 (overlapped peaks, $2 \mathrm{H}, 19-\mathrm{H}, 36-\mathrm{H}) 7.24(\mathrm{t}, J=7.8$ $\mathrm{Hz}, 2 \mathrm{H}, 20-\mathrm{H}, 35-\mathrm{H}) 7.29$ (dd, $J=1.8,2.4 \mathrm{~Hz}, 2 \mathrm{H}, 37-$ $\mathrm{H}, 44-\mathrm{H}) ; \delta_{\mathrm{C}}\left(150 \mathrm{MHz}, \mathrm{CDCl}_{3}\right) 25.86$ (27-C, 28-C), 26.40 (40-C, 41-C), 33.01 (26-C, 29-C), 67.45 (3-C, 16-C), 69.93 (4-C, 15-C), 71.02, 71.04, 71.08(6-C, 7C, 9-C, 10-C, 12-C, 13-C), 75.41 (25-C, 30-C, 39-C, 42-C), 102.43 (23-C, 32-C) 111.19 (37-C, 44-C) 116.60 (19-C, 36-C) 119.91 (21-C, 34-C) 129.31 (20-C, 35-C) 140.07 ( 22-C, 33-C), 159.43 (1-C, 18C). MALDI-TOF, $\mathrm{m} / \mathrm{z}=637.3 \quad[\mathrm{M}+\mathrm{Na}]^{+}, \quad 653.3$ 
$[\mathrm{M}+\mathrm{K}]^{+} . \mathrm{C}_{35} \mathrm{H}_{49} \mathrm{O}_{10}$ requires: $\mathrm{C}, 66.75 ; \mathrm{H}, 7.84 \%$; found: C, 66.56; H, 7.69\%.

$2,5,8,11,14,17,20,27,34,41,46-$ undecaoxahexacyclo $\left[34.3 .1^{11,25} \cdot 2^{26,29} \cdot 2^{29,32} \cdot 2^{32,35} 1^{1,36}\right]$ heptatetraconta-1 (47),21,23, 25(40),36,38-hexaena (7a). White solid, mp123-123.5 ${ }^{\circ} \mathrm{C}$, column chromatography, (dichloromethane/ethylacetate $=3 / 2 ; R_{\mathrm{f}}=0.18$ ) $9.0 \%$ yield. $\delta_{\mathrm{H}}\left(600 \mathrm{MHz}, \mathrm{C}_{6} \mathrm{D}_{6}\right) 0.48(\mathrm{~s}, 4 \mathrm{H}, 30-\mathrm{H}, 31-\mathrm{H})$, 1.89 (s, 4H, 43-H, 44-H), $3.15(\mathrm{~d}, J=11.1 \mathrm{~Hz}, 4 \mathrm{H}$, $28-\mathrm{H}_{\mathrm{ax}}, 33-\mathrm{H}_{\mathrm{ax}}, 42-\mathrm{H}_{\mathrm{ax}}, 45-\mathrm{H}_{\mathrm{ax}}$ ) 3.42 (overlapped peaks, 16H, 6-H, 7-H, 9-H, 10-H, 12-H, 13-H, 15-H, $16-\mathrm{H}), 3.50(\mathrm{t}, J=4.8 \mathrm{~Hz}, 4 \mathrm{H}, 4-\mathrm{H}, 18-\mathrm{H}), 3.75(\mathrm{~d}$, $\left.J=11.1 \mathrm{~Hz}, 4 \mathrm{H}, 28-\mathrm{H}_{\mathrm{eq}}, 33-\mathrm{H}_{\mathrm{eq}}, 42-\mathrm{H}_{\mathrm{eq}}, 45-\mathrm{H}_{\mathrm{eq}}\right) 3.83$ (t, $J=4.8 \mathrm{~Hz}, 4 \mathrm{H}, 3-\mathrm{H}, 19-\mathrm{H}$,) $5.34 \mathrm{(s}, 2 \mathrm{H}, 26-\mathrm{H}, 35-$ H), 6.85 (ddd, $J=1.2,3,2.4 \mathrm{~Hz}, 2 \mathrm{H}, 22-\mathrm{H}, 39-\mathrm{H}$ ), 7.04 (d, $J=7.8 \mathrm{~Hz}, 2 \mathrm{H}, 24-\mathrm{H}, 37-\mathrm{H}), 7.1(\mathrm{t}, J=7.8 \mathrm{~Hz}$, $2 \mathrm{H}, 23-\mathrm{H}, 38-\mathrm{H}), 7.69$ (dd, J=1.2, $2.4 \mathrm{~Hz}, 2 \mathrm{H}, 40-\mathrm{H}$, $47-\mathrm{H}) ; \delta_{\mathrm{C}}\left(150 \mathrm{MHz}, \mathrm{C}_{6} \mathrm{D}_{6}\right) 26.37$ (43-C, 44-C), 26.73 (30-C, 31-C), 33.19 (29-C, 32-C), 67.14 (3-C, 19-C), 70.48 (4-C, 18-C), 71.61, 71.63 (6-C, 7-C, 9C, 10-C, 12-C, 13-C, 15-C, 16-C), 75.66 (28-C, 33C, 42-C, 45-C), 103.01 (26-C, 35-C), 112.89 (40-C, 47-C), 116.51 (22-C, 39-C), 120.47 (24-C, 37-C), 129.69 (23-C, 38-C), 141.73 (25-C, 36-C), 160.37 (1-C, 21-C). MALDI-TOF, m/z=681.3 [M+Na $]^{+}$; $697.5[\mathrm{M}+\mathrm{K}]^{+} . \mathrm{C}_{36} \mathrm{H}_{50} \mathrm{O}_{11}$ requires: $\mathrm{C}, 65.64 ; \mathrm{H}$, 7.65\%; found: C, $65.82 ; \mathrm{H}, 7.53 \%$.

$2,5,8,11,14,17,20,27,34,41,44,47,50,53,56,59,66,73$, 80,85,88,93-docosaoxaundecacyclo[ $73.3 .2^{26,29}$. $\left.2^{29,32} \cdot 2^{32,35} \cdot 2^{65,68} \cdot 2^{68,71} \cdot 2^{71,74} \cdot 1^{1,75} \cdot 1^{21,25} \cdot 1^{36,40} \cdot 1^{60,64}\right]-$ tetranonaconta-21,23,36,38,60,62,75,77,1(94),79, 86,87-dodecaene (7b; anti -anti). White solid, $\mathrm{mp}$ 95-96 ${ }^{\circ} \mathrm{C} ; \mathrm{rt}=23.45 \mathrm{~min}$. (HPLC); $22.0 \%$ yield. $\delta_{\mathrm{H}}$ $\left(400 \mathrm{MHz}, \mathrm{CD}_{2} \mathrm{Cl}_{2}\right) 1.23(\mathrm{t}, J=6.8 \mathrm{~Hz}, 8 \mathrm{H}, 30-\mathrm{H}, 83-$ $\mathrm{H}, 69-\mathrm{H}, 91-\mathrm{H}), 1.76(\mathrm{t}, J=6.8 \mathrm{~Hz}, 8 \mathrm{H}, 31-\mathrm{H}, 82-\mathrm{H}$, $70-\mathrm{H}, 90-\mathrm{H}), 3.57$ (d, $J=11.4 \mathrm{~Hz}, 8 \mathrm{H}, 28-\mathrm{H}_{\mathrm{ax}}, 33-\mathrm{H}_{\mathrm{ax}}$, $\left.67-\mathrm{H}_{\mathrm{ax}}, 72-\mathrm{H}_{\mathrm{ax}}, 81-\mathrm{H}_{\mathrm{ax}}, 84-\mathrm{H}_{\mathrm{ax}}, 89-\mathrm{H}_{\mathrm{ax}}, 92-\mathrm{H}_{\mathrm{ax}}\right), 3.59$ (s, 16H, 9-H, 10-H, 12-H, 13-H, 48-H, 49-H, 51-H, 52-H), 3.61-3.62 (overlapped peaks, 8H, 7-H, 15-H, 46-H, 54-H), 3.65-3.67 (overlapped peaks, 8H, 6- H, $16-\mathrm{H}, 45-\mathrm{H}, 55-\mathrm{H}), 3.80$ (t, $J=4.8 \mathrm{~Hz}, 8 \mathrm{H}, 4-\mathrm{H}, 18-\mathrm{H}$, $43-\mathrm{H}, 57-\mathrm{H}), 3.99$ (d, $J=11.4 \mathrm{~Hz}, 8 \mathrm{H}, 28-\mathrm{H}_{\mathrm{eq}}, 33-\mathrm{H}_{\mathrm{eq}}$, $\left.67-\mathrm{H}_{\mathrm{eq}}, 72-\mathrm{H}_{\mathrm{eq}}, 81-\mathrm{H}_{\mathrm{eq}}, 84-\mathrm{H}_{\mathrm{eq}}, 89-\mathrm{H}_{\mathrm{eq}}, 92-\mathrm{H}_{\mathrm{eq}}\right), 4.11$ $(\mathrm{t}, J=4.8 \mathrm{~Hz}, 8 \mathrm{H}, 3-\mathrm{H}, 19-\mathrm{H}, 42-\mathrm{H}, 58-\mathrm{H}), 5.34(\mathrm{~s}$, $4 \mathrm{H}, 26-\mathrm{H}, 35-\mathrm{H}, 65-\mathrm{H}, 74-\mathrm{H}$ ), 6.88 (ddd, $J=2.4,4.2$, $8 \mathrm{~Hz}, \quad 4 \mathrm{H}, \quad 22-\mathrm{H}, \quad 39-\mathrm{H}, \quad 61-\mathrm{H}, \quad 78-\mathrm{H}), \quad 7.02$ (overlapped peaks, 4H, 24- $, 37-\mathrm{H}, 63-\mathrm{H}, 76-\mathrm{H}$ ), 7.04 (overlapped peaks, 4H, 79-H, 86- H, 87-H, 94H), 7.25 (t, J=8 Hz, 4H, 23-H, 38-H, 62-H, 77-H); $\delta_{\mathrm{C}}$ $\left(100 \mathrm{MHz}, \mathrm{CD}_{2} \mathrm{Cl}_{2}\right)$ 25.76, 27.16 (30-C, 31-C, 69-C, 70-C, 83-C, 82-C, 90-C, 91-C), 33.17 (29-C, 32-C, 68-C, 71-C), 68.10 (3-C, 19-C, 42-C, 58-C), 70.21 (4-C, 18-C, 43-C, 57-C), 71.13 (7-C, 9-C, 10-C, 12C, 13-C, 15-C, 46-C, 48-C, 49-C, 51-C, 52-C, 54-C), 71.34 (6-C, 16-C, 45-C, 55-C), 75.73 (28-C, 33-C, 72-C, 67-C, 81-C, 84-C, 89-C, 92-C), 102.35 (26-C, 35-C, 65-C, 74-C), 112.83 (79-C, 86-C, 87-C, 94-C), 115.55 (22-C, 39-C, 61-C, 78-C), 119.25 (24-C, 37-
C, 63-C, 76-C), 129.72 (23-C, 38-C, 62-C, 77-C), 140.97 (25-C, 36-C, 64-C, 75-C), 159.37 (1-C, 21-C, 40-C, 60-C). MS (ESI): $1339.8[\mathrm{M}+\mathrm{Na}]^{+}, 1355.2$ $[\mathrm{M}+\mathrm{K}]^{+} . \mathrm{C}_{72} \mathrm{H}_{100} \mathrm{O}_{22}$ requires: $\mathrm{C}, 65.63 ; \mathrm{H}, 7.64 \%$; found: $\mathrm{C}, 65.48 ; \mathrm{H}, 7.70 \%$.

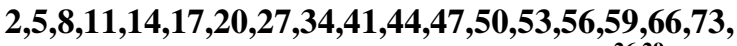
$80,85,88,93-$ docosaoxaundecacyclo $\left[73.3 .2^{26,29}\right.$. $\left.2^{29,32} \cdot 2^{32,35} \cdot 2^{65,68} \cdot 2^{68,71} \cdot 2^{71,74} \cdot 1^{1,75} \cdot 1^{21,25} \cdot 1^{36,40} \cdot 1^{60,64}\right]-$ tetranonaconta-21,23,36,38,60,62,75,77,1(94),79, 86,87-dodecaene (7b'). White solid, $\mathrm{mp} 88-89^{\circ} \mathrm{C}$, rt $=22.03$ min. (HPLC); $21.0 \%$ yield. $\delta_{\mathrm{H}}(400$ MHz,THF-d8) 1.07 (s, 4H, 30-H, 31-H),1.20 (t, $J=6.8 \mathrm{~Hz}, 69-\mathrm{H}, 91-\mathrm{H}), 1.76(\mathrm{t}, J=6.8 \mathrm{~Hz}, 70-\mathrm{H}, 90-$ H) $1.89(\mathrm{~s}, 4 \mathrm{H}, 82-\mathrm{H}, 83-\mathrm{H}), 3.51(\mathrm{t}, J=11.2 \mathrm{~Hz}, 8 \mathrm{H}$, $28-\mathrm{H}_{\mathrm{ax}}, 33-\mathrm{H}_{\mathrm{ax}}, 84-\mathrm{H}_{\mathrm{ax}}, 81-\mathrm{H}_{\mathrm{ax}}, 89-\mathrm{H}_{\mathrm{ax}}, 92-\mathrm{H}_{\mathrm{ax}}, 67-$ $\mathrm{H}_{\mathrm{ax}}, 72-\mathrm{H}_{\mathrm{ax}}$ ), 3.54-3.60 (overlapped peaks, $32 \mathrm{H}, 6-\mathrm{H}$, 7-H, 9-H,10-H, 12-H, 13-H, 15-H, 16-H, 45-H,46-H, 48-H, 49-H, 51-H, 52-H, 54-H, 55-H), 3.73-3.77 (overlapped peaks, 8H, 4-H, 18- H, 43-H, 57-H), 4.00 (t, $J=11.2 \mathrm{~Hz}, 8 \mathrm{H}, 28-\mathrm{H}_{\mathrm{eq}}, 33-\mathrm{H}_{\mathrm{eq}}, 84-\mathrm{H}_{\mathrm{eq}}, 81-\mathrm{H}_{\mathrm{eq}}, 89-$ $\mathrm{H}_{\mathrm{eq}}, 92-\mathrm{H}_{\mathrm{eq}}, 67-\mathrm{H}_{\mathrm{eq}}, 72-\mathrm{H}_{\mathrm{eq}}$ ), 4.04-4.07 (overlapped peaks, 8H, 3-H, 19-H, 42-H, 58-H), 5.33 (s, 4H, 26$\mathrm{H}, 35-\mathrm{H}, 65-\mathrm{H}, 74-\mathrm{H}$ ), 6.82-6.85 (overlapped peaks, $4 \mathrm{H}, 22-\mathrm{H}, 39-\mathrm{H}, 61-\mathrm{H}, 78-\mathrm{H}$ ), 6.94-7.00 (overlapped peaks, 4H, 24-H, 37-H, 63-H, 76-H), 7.03-7.05 (overlapped peaks, 79-H, 86-H, 87-H, 94-H), 7.147.19 (overlapped peaks, 23-H, 38-H, 62-H, 77-H); $\delta \mathrm{C}(100 \mathrm{MHz}, \mathrm{THF}-\mathrm{d} 8)$ 33.50, 33.57 (9-C, 10-C, 12C, 13-C, 48-C, 49-C, 51-C, 52-C), 68.55 (3-C, 19-C, 42-C, 58-C), 70.73 (4-C, 18-C, 43-C, 57-C), 71.73, 71.76, 71.86 (6-C, 7-C, 15-C, 16-C, 45-C, 46-C, 54C, 55-C), 75.99 (28-C, 33-C, 81-C, 84-C, 89-C, 67C, 72-C, 92-C), 102.76 (26-C, 35-C, 65-C, 74-C), 113.6 (79-C, 86-C, 87-C, 94-C), 115.4 (22-C, 39-C, 61-C, 78-C), 119.53 (24-C, 37-C, 63-C, 76-C), 129.55 (23-C, 38-C, 62-C, 77-C), 141.87 (25-C, 36C, 64-C, 75-C), 160.03 (21-C, 40-C, 60-C, 1-C). MS (ESI): $1339.9[\mathrm{M}+\mathrm{Na}]^{+}, 1355.2[\mathrm{M}+\mathrm{K}]^{+} . \mathrm{C}_{72} \mathrm{H}_{100} \mathrm{O}_{22}$ requires: $\mathrm{C}, 65.63 ; \mathrm{H}, 7.64 \%$; found: $\mathrm{C}, 65.77 ; \mathrm{H}$, $7.76 \%$.

\section{ACKNOWLEDGMENTS}

"Le Conseil Géneral de la Région Haute-Normandie" is gratefully acknowledged for the fellowship given to Maria Carmen Florian. CNCSIS is acknowledged for the partial financial support of this work (grants A $1736 / 2005 ; 1315 / 2006$ and $T_{d} 18 / 2002$ ).

\section{REFERENCES}

(1) Zhang, X. X.; Bradshaw, J. S.; Izatt, R. M. Chem. Rev. 1997, 97, 3313.

(2) Izatt, R. M.; Pawlak, K.; Bradshaw, J.S. Chem. Rev. 1991, 91, 1721.

(3) Klein, E.; Crump, M. P.; Davis, A. P. Angew. Chem. Int. Ed. 2005, 44, 298. 
(4) Matsumoto, M.; Hamaoka, K; Takashima, Y; Yokokawa, M.; Yamada, K.; Watanabe, N.; Ijuin, H. K. Chem. Commun. 2005, 808

(5) Huang, F.; Guzei, I. A.; Jones, J. W.; Gibson H. W. Chem. Commun. 2005, 1693.

(6) Huang, F.; Zhou, L.; Jones, J. W.; Gibson, H. W.;

Ashraf-Khorassani, M. Chem. Commun. 2004, 2670.

(7) Ilioudis, C. A.; Tocher, D. A.; Steed, J. W. J. Am.

Chem. Soc. 2004, 126, 12395.

(8) Gallant, A. J.; Patrick, B. O.; MacLachlan; M. J. J. Org. Chem. 2004, 69, 8739.

(9) Galaup, C.; Couchet, J. M.; Bedel, S.; Tisnès, P.; Picard C. J. Org. Chem. 2005, 70, 2274

(10) Player, T. N.; Shinoda, S.; Tsukube, H. Org. Biomol. Chem. 2005, 3, 1615.

(11) García, F.; Goodman, J. M.; Kowenicki, R. A.; Kuzu, I.; McPartlin, M.; Silva, M. A.; Riera, L.; Woods, A. D.; Wright D. S. Chem. Eur. J. 2004, 10, 6066.

(12) Rebek, J. Jr. Angew. Chem. Int. Ed. 2005, 44, 2068.

(13) Koskela, S. J. M.; Fyles, T. M.; James, T. D. Chem. Commun. 2005, 945.

(14) Huang, F.; Gibson, H. W. Chem. Commun. 2005, 1696.

(15) Mahoney, J. M.; Stucker, K. A.; Jiang, H.; Carmichael, I.; Brinkmann, N. R.; Beatty, A. M.; Noll, B. C.; Smith, B. D. J. Am. Chem. Soc. 2005, 127, 2922.

(16) Li, Z. B.; Lin, J.; Zhang, H. C.; Sabat, M.; Hyacinth, M.; Pu, L. J. Org. Chem. 2004, 69, 6284.

(17) Nakahara, Y.; Kida, T.; Nakatsuji, Y.; Akashi, M. Org. Biomol. Chem. 2005, 3, 1787.

(18) Kim, S. K.; Singh, N. J.; Kim, S. J.; Swamy, K. M. K.; Kim, S. H.:Lee, K. H.; Kimb, K. S.; Yoona, J. Tetrahedron 2005, 61, 4545.

(19) Höger, S.; Chem. Eur. J. 2004, 10, 1320.

(20) Bag, B.; Bharadwaj, P. K Chem. Commun. 2005, 513.

(21) Sly, J.; Kasák, P.; Nadal, E. G.; Rovira, C.; Górriz, L.; Thordarson, P.; Amabilino, D. B.; Rowan, A. E.; Nolte, R. J. M. Chem. Commun. 2005, 1255.

(22) Tönshoff, C.; Merz, K.; Bucher, G. Org. Biomol. Chem. 2005, 3, 303.

(23) Steed, J. W.; Atwood, J. L. Supramolecular Chemistry, Wiley\&Sons, New York, 2000, p. 87.

(24) Blankenstein, J.; Zhu, J. Eur. J. Org. Chem. 2005, 1949.

(25) Diederich, F.; Stang, P.J. Templated Organic Synthesis, Wiley-VCH, Weinheim, Germany, 2000, p. 4.

(26) Hiraga, H.; Morozumi, T.; Nakamura, H. Eur. J. Org. Chem 2004, 4680.

(27) Jaunzems, J.; Oelze, B.; Kirschning, A. Org. Biomol. Chem. 2004, 2, 3448.

(28) Robertson, J.; Meo, P.; Dallimore, J. W. P.; Doyle, B. M.; Hoarau, C.; Org. Lett., 2004, 6, 3861.

(29) Piatek, P.; Gruza, M. M.; Jurczak, J. Tetrahedron: Asymmetry 2001, 12, 1763.

(30) Wenzel, T. J.; Thurston, J. E.; Sek, D. C.; Joly, J. P. Tetrahedron: Asymmetry 2001, 12, 1125.

(31) Bakó, T.; Bakó, P.; Szöllõsy, Â.; Czugler, M.; Keglevich, G.; Tõke, L. Tetrahedron: Asymmetry, 2002, 13, 203.

(32) Wybrow, R.A.J.; Johnson, L.A.; Auffray, B.; Moran, W.J.; Adams, H.; Harrity, J.P.A. Tetrahedron Lett. 2002, 43, 7851.

(33) Ito, T.; Tokuyasu, T.; Masuyama, A.; Nojima, M.; McCullough, K.J. Tetrahedron, 2003, 59, 525.
(34) Garcia, C.; Pointud, Y.; Jeminet, G.; Dugat, D. Tetrahedron Lett. 1999, 40, 4933.

(35) Garcia, C.; Guyot, J.; Jeminet, G.; Leize-Wagner, E.; Nierengarten, H.; Van Dorsselaer, A. Tetrahedron Lett. 1999, 40, 4997.

(36) Bakó, P.; Novák, T.; Ludányi, K.; Pete, B.; Tõke, L.; Keglevich, G. Tetrahedron: Asymmetry 1999, 10, 2373.

(37) Galan, M. C.; Venot, A. P.; Glushka, J.; Imberty, A.; Boons, G. J. J. Am. Chem. Soc. 2002, 124, 5964.

(38) Grosu, I.; Bogdan, E.; Plé, G.; Toupet, L.; Ramondenc, Y.; Condamine, E.; Peulon-Agasse, V.; Balog, M. Eur. J. Org. Chem. 2003, 3153.

(39) Balog, M.; Grosu, I.; Plé, G.; Ramondenc, Y.; Toupet, L.; Condamine, E.; Lange, C.; Loutelier-Agasse, C.; Peulon-Agasse, V.; Bogdan, E. Tetrahedron 2004, 60, 4789.

(40) Grosu, I. ; Mager, S. ; Plé, G.; Mesaros, E. Tetrahedron 1996, 52, 12783.

(41) Cismas, C.; Terec, A.; Mager, S.; Grosu, I. Curr. Org. Chem., 2005, 9,1287.

(42) Feuerbacher, N; Vögtle, F.; Windscheidt, J.; Poetsch, E.; Nieger, M. Synthesis, 1999, 117.

(43) Campbell, T. W.; Foldi,V. S. J. Org. Chem. 1961, 26 , 4654.

(44) Eliel, E. L.; Wilen, S. H.; Mander, L. N. Stereochemistry of Organic Compounds, Wiley\&Sons, New York, 2004, p. 1178.

(45) Nonius,. KappaCCD Software. Nonius BV, Delft, 1999, The Netherlands

(46) Otwinowski, Z.; Minor, W. Processing of X-ray Diffraction Data Collected in Oscillation Mode, in Methods in Enzymology, Vol. 276, Macromolecular Crystallography, Part A, edited by Carter, C. W.; Sweet, R. M. Academic Press, London, 1997, p. 307.

(47) Altomare, A.; Burla, M. C.; Camalli, M.; Cascarano, G.; Giacovazzo, C.; Guagliardi, A.; Moliterni, A.G.G.; Polidori, G.; Spagna R., Sir97: a new tool for crystal structure determination and refinement. $J r$ of Applied Crystallography 1998, 31, 74.

(48) Sheldrick, G.M. SHELX97. Program for the Refinement of Crystal Structures, Univ. of Göttingen, 1997, Germany.

(49) International Tables for X-ray Crystallography Vol.C. Wilson A.J.C. (Editor) Kluwer Academic Publishers, 1992, Dordrecht, Germany

(50) Spek, A.L. PLATON. A multipurpose crystallographic tool, Utrecht University, 1998, Utrecht, The Netherlands. 